\title{
Family Solanaceae: Taxonomy and modern trends
}

Masood Majaz Ganaie ${ }^{1 *}$, Vaseem Raja ${ }^{1,2}$, Zaffar Ahmad Reshi ${ }^{2}$ \& Vijeshwer Verma ${ }^{3}$

${ }^{1}$ Department of Botany Govt. Degree College Tral, J\&K India-192123

${ }^{2}$ Department of Botany Kashmir University Srinagar, J\&K India-190006

${ }^{3}$ Biotechnology Division Indian Institute of Integrative Medicine Jummu J\&K India.

Received: 12-07-2018; Revised: 23-07-2018; Accepted: 29-07-2018

\begin{abstract}
Solanaceae belongs to that group of families, which are included in almost all angiosperm classifications indicating naturalness of the family. The family being one of the most evolutionarily successful and advanced taxa shows astonishing level of diversity reflected in the form of various types of adaptations. The high level of diversity within the family in addition to other unusual features have reflected in poor understanding of its phylogenetics. Fossil record of angiosperms particularly of Solanaceae) is very meager and relatively recent, so use of morphology and other conventional characters is not convincing in revealing true phylogeny of the family. This all has necessitated using alternative marker types in phylogenetic analysis of the family. Since advent of molecular biology molecular markers have been constantly refined to serve the purpose. Solanaceous species, such as tomato, potato, chilli pepper, tobacco, and petunia serve as model systems for the investigation of molecular and agronomic questions, and the family is the subject of intensive phylogenetic studies that are providing new insights into species boundaries and generic relationships. Results from recent morphological, molecular, and biosystematic research have shed new light on the systematic relationships in the family at virtually all taxonomic levels from subfamily to variety.
\end{abstract}

Key words: Solanaceae, petunia, phylogenetic studies, biosystematic research

\section{Introduction}

Family Solanaceae is one the largest and economically most important families of angiosperms, including important food, spice, and drug plants (D’Arcy, 1979). There has been much change in recent years regarding generic circumscription in the family. In 1979, D'Arcy estimated it to contain 83 genera and 2671 species, but the most recent estimate is that the family includes more than 3000 species. Approximately half the species in the family are included in the widespread, morphologically diverse, and economically important genus Solanum. The family is nearly cosmopolitan in distribution, found throughout tropical and temperate regions, but with a concentration of diversity in Australia and Latin America.

Diversity within this family is also indicated by the variety of life forms of the taxa included in this family, ranging from ephemeral herbs (Leptoglossis spp. and Schizanthus spp.) to large trees (Duckeodendron spp.). Characteristic morphological attributes of the family include presence of exstipulate, alternate or rarely opposite leaves and with hypogynous, regular or nearly regular cymose flowers. Five-lobed calyx and sympetalous corolla, which is also 5-lobed, with lobes being induplicatevalvate or plicate in the bud, are also found in the family. Epipetalous stamens, mostly equal in number to petals (in certain cases fewer) and arranged alternately with them, are equal in length

\section{*Corresponding Author:}

Mr. Masood Majaz Ganaie,

Department of Botany,

Government Degree College,

Tral, J\&K -192123, India.

E-mail: masoodmg@gmail.com and perfect except in certain genera. Gynoecium consists of two united carpels and very rarely three or five carpels fuse to form the gynoecium. Ovules and seeds are numerous, a feature differentiating Solanaceae from Convolvulaceae. Fruit is a berry or capsule and most of the solanaceous members have a basic set of twelve chromosomes.

Perusal of the literature reveals that one of the earliest references to the Solanaceae is in the Dioscorides Codex of 815 A.D., and it is here that many of the present day Solanaceous members have been described (D'Arcy, 1979). While Casper Bauhin's (1623) concept of Solanaceae as a group was gaining general acceptance, Linnaeus (1753) recognized two groups, which loosely encompassed the present day Solanaceae. However, his grouping on the basis of number of stamens led to many unnatural assemblages. It was ultimately Antoine Laurent de Jussieu (1789) who established the family Solanaceae and since then this family has been reviewed and re-examined by many taxonomists. Like other large angiosperm families, such as Scrophulariaceae (Olmstead and Reeves, 1995), Solanaceae is also represented by several core genera, which have been assigned to this family in all the classificatory treatments (D'Arcy 1979, 1991). While some workers have included a number of allied genera or groups of genera in this family others have placed them in related families and still others have even segregated them into separate 
families (Bentham and Hooker, 1862-1883; Engler and Prantl, 1887-1915; Hutchinson, 1973; Cronquist, 1981; Takhtajan, 1997 and APG, 2009). This inconsistent systematic treatment is largely due to the presence of unusual character combinations in these allied genera. Either they lack the characters typical of the family or have attributes characteristic of another family. It is because of this inconsistent systematic position of several genera within this family. The uncertain taxonomic status of taxa, briefly presented above, is a result of factors, such as the origin of the family in an area (tropical America) which is still largely unexplored (D'Arcy, 1979), certain important morphological trends within the family that are contrary to those prevalent in other angiosperms (Stebbins, 1974), occurrence of annual habit and strongly zygomorphic flowers in species belonging to basal clades of Solanaceae and this also is exactly opposite to what is prevalent in other angiosperms (Stebbins, 1974), and unusual hyperdiversity of genus Solanum which makes Solanaceae interesting from an evolutionary standpoint (Knapp et al., 2004) as well. It is for these reasons that Solanaceae is called as 'paradoxical family' (Heiser, 1969 and Knapp et al., 2004).

\section{Molecular markers vs systematic position}

To resolve the taxonomic riddles within Solanaceae, recourse has been taken to modern and revolutionary molecular markers, which, since their development and use, have revolutionized the entire scenario of biological sciences. These markers have acted as versatile tools for taxonomy and their application in Solanaceae is expected to result in a classification that is more predictive with respect to interpreting evolution. Morphological markers, though indispensable both to taxonomy as well as phylogeny have the universal disadvantage of not lending themselves to meaningful statistical comparisons and also are less used because of the controversies about character homologies (Scotland et al., 2003). These anomalies have curtailed the role of morphology in taxonomic and phylogenetic description of the family Solanaceae (Knapp, 2001) and invoked use of other types of markers, particularly, molecular markers. Molecular markers present diverse applications to efficiently obtain useful genetic information (Karp et al., 1997) and so have been utilized for the analysis of the genetic diversity in a number of plant species like Solanum tuberosum, S. melonogena, Petunia spp, Nicotiana spp etc. It is here emphasis that results of molecular markers are not in general antagonistic to that by other conventional markers (Spooner et al., 2006) but in most of the instances they provide complementary evidences. However, use of a particular molecular marker type depends upon the nature of the study and the extent of taxonomic resolution desired (Junli et al., 2000; Zhang et al., 2000 and Sylvain et al., 2000). Since it is extremely difficult to find an ideal DNA marker that meets all the necessary criteria, a set of markers is commonly used to unravel a significant proportion of genetic diversity (Weising et al., 1995). Various types of DNA-based molecular techniques (Botstein et al., 1980; Joshi et al., 1999) are utilized to evaluate DNA polymorphism and the available DNA markers are categorized as: DNA band-based, hybridizationbased and sequence -based markers. Band based molecular markers include randomly amplified polymorphic DNA (RAPD), inter-simple sequence repeats (ISSR), simple sequence repeats (SSR), polymerase chain reaction restriction fragment length polymorphism (PCR-RFLP) and amplified fragment length polymorphism (AFLP) etc.

\section{RAPD and ISSR Markers}

Being efficient, simple and inexpensive, RAPD has been employed in many taxonomic and phylogenetic studies of Solanaceae (Spooner et al., 1995; Rio and Bamberg et al., 2000 and 2004; Singh et al., 2006). Study of Spooner et al., (1995) showed the applicability of RAPDs for both intra-and interspecific studies in section Etuberosum of Solanum. Singh et al., (2006) used RAPD technique as a tool for assessing genetic diversity and species relationships among 28 accessions of Solanum species. It discriminated all the accessions of eggplants and the resulting dendrogram showed that Solanum incanum was closest to $S$. melonogena and then to $S$. nigrum. Also RAPD markers efficiently distinguished heterogeneous populations of wild potato from closely related tetraploid species, $S$. oplocense, $S$. gourlayi and $S$. tuberosum ssp. andigena, suggesting that it is not a duplicate of these species (Rio and Bamberg, 2004). Besides, RAPD profiles clearly differentiated populations within highly heterogeneous tetraploid of $S$. sucrense and were useful for determining germplasm organization within the potato species (Rio and Bamberg, 2004). Similar conclusion was obtained by Demeke et al., (1993), Xu et al., (1993) for Solanum tuberosum and other related species. Applicability of RAPD and semi-arbitrary primers (targeting intron-exon boundaries) was advocated by Przetakiewicz et al., (2002) in Solanum tuberosum. Suganda et al., (2006) successfully applied RAPD to distinguish three Indonesian species Brugmansia, which, otherwise, were indistinguishable by morphological or metabolite analysis. This study revealed that each species had different DNA fragment patterns, thus allowing each species to be individually identified. Based on RAPD analysis of 53 species and cultivars of the genus Lycopersicon (sensu lato), Kochieva et al., (2002a) reported more divergence among crosspollinating tomato species than self-pollinating species. Karihaloo et al., (1995) used RAPD for studying variations in Solanum melonogena. Notwithstanding these useful systematic applications, RAPD analysis did not support assumption of Solanum aethiopicum and $S$. anguivi as two separate species (Stedje and Bukenya-Ziraba 2003). Egashira et al., (2000) also found RAPD 
markers helpful in assessing genetic diversity within Lycopersicon peruvianum and L. chilense. However, it needs to be emphasized that it is essential to set up a negative control reaction as RAPD primers potentially find their way during amplification in any prokaryotic and eukaryotic DNA, which may produce false positive results. Besides, RAPD and its modified versions (Caetano-Anolles et al., 1991; Sivolap and Kalendar, 1995; Aagaard et al., 1998 and Atienzar et al., 2000) have reproducibility problems and due to non-stringent conditions a certain band may not show fidelity for a given sample at different times or in different laboratories.

Another band based molecular marker, named as ISSR (Zietkiewicz et al., 1994), is amplified by PCR in presence of a primer complementary to a target microsatellite. Here target of the amplification is the region between two simple sequence repeat (SSRs) regions, which are inverted in orientation and within amplifiable range. It is generally assumed that there are many SSR motifs in a eukaryotic genome (Li and Ge, 2000) and copies of many of them are in opposite orientation in vicinity. Such amplification does not require genome sequence information and leads to multilocus and highly polymorphic patterns (Zietkiewicz et al., 1994; Tsumura et al., 1996. But one has to screen a genome for presence of different SSR motifs with above stated characteristics. Each band corresponds to a DNA sequence delimited by two inverted microsatellites. Like RAPDs, ISSR markers are quick and easy to handle, but they have higher reproducibility because of longer length of their primers. There are two types of ISSR markers: one is anchored and another is non-anchored. In the former, one or more extra nucleotides are at $3^{\prime}$ end of the primer, which allows it to anneal specifically at the junction of SSR and ISSR regions. Further, such extension of a nucleotide leads to more specification of the primer. In non-anchored version there is no extension in primer at $3^{\prime}$ end giving it more freedom in amplification of unknown ISSR sequence. Absence of a particular band or variation of band length could also signify that an SSR site (ISSR primer binding site) might have been lost or a chromosomal structure rearrangement may have taken place. Because ISSRs are a variant of the RAPD technique, they have inherited many of the problems that beset RAPD (band scoring and homology). Bornet and Branchard (2001) in an attempt to cope with these difficulties modified their PCR protocol raising annealing temperature till constant amplification pattern is obtained and found this version more effective. Polymorphisms are mostly of the dominant type because of changes in the anchoring nucleotide, but codominant types occur if length of the intervening space between the microsatellites has changed (Andersen, 2000). In Solanaceae, ISSR markers have been mainly used for cultivar identification (Prevost and Wilkinson, 1999). Pérez de la Torre and Escandón (2006) used anchored ISSR primers for the fingerprint generation in Nierembergia linariaefolia and found that six out of the seven primers used, discriminated all the individuals involved in the study. Kumar et al., (2001) used ISSR markers successfully for infraspecific identification in Capsicum annuum. Using non-anchored ISSR primers, Kochieva et al., (2002b) found species-specific ISSR fragments for each tomato species.

\section{RFLP, AFLP and other Markers}

In addition to these markers, RFLP has also been used for elucidation of systematic position of taxa within Solanaceae (Prince et al., 1992). This technique involves cutting up the DNA into a number of fragments using a variety of restriction enzymes, separating the resultant fragments of variable size using electrophoresis, followed by visualization of the banding profile of fragments using ethidium bromide. Presence or absence of bands can be scored as in other band-based techniques and the banding profile directly reflects the position and frequency of restriction sites within the DNA (Sylvain et al., 2000). In case of complex genome where there are more chances of band overlapping, labelled probes are used through hybridization to determine the presence of particular type of DNA fragment. Because of being ubiquitous throughout the plant, highly heritable and relatively highly polymorphic, RFLPs are superior genetic markers and have been used in polymorphism studies, cultivar identification and for phylogenetic studies. However, a major drawback of hybridization based RFLP is that its application is technically difficult, relatively slow, labour intensive and may involve expensive and sometimes radioactive / toxic reagents. A modified version of RFLP called as PCR-RFLP or cleaved amplified polymorphic sequences (CAPS) have been developed where a PCR locus is first amplified with PCR and then it is subjected to restriction enzyme digestion. Such digests are compared for their differential migration during electrophoresis (Koniecyzn and Ausubel, 1993 and Jarvis et al., 1994). PCR primer for this process can be synthesized based on the sequence information available in databank of genomic or cDNA sequences or cloned RAPD bands. Like other marker types, RFLP has been used in taxonomic studies of various taxa of Solanaceae.

Simple sequence repeat (short tandem repeats or simple sequence length polymorphisms or simply microsatellites) markers are based on difference in tandem repeats of sequence units generally 2-8 bp in length (Godwin et al., 2001). SSR loci are particularly ubiquitous in plant genome (Kubis et al., 1998; Li and Ge, 2001 and Rakoczy-Trojanowska and Bolibok, 2004). The principle of SSR polymorphism is the presence of variability either in number of repeats within SSR or in priming sites. SSRs can be amplified by using primers that flank 
these regions and the same are designed by searching the DNA sequence banks for SSR loci of related species or by screening genomic libraries. In certain cases SSR primers from one-species have been used in phylogenetically distant species and have fulfilled the purpose of exploring the intra and inter-specific diversity (Smelcerovic et al., 2006). In spite of many practical difficulties (Kelly and Willis, 1998), SSR markers are ideal for genome mapping as well as for population genetic and diversity studies. Hence Marcucci-Poltri et al., (1998) used SSR markers for analysing genetic relationship in the genus Solanum sub-section Potatoe. Bindler et al., (2007) used them for genome evaluation of tobacco with satisfactory results. Guzmán et al., (2005), while faced difficulty to distinguish accessions of Capsicum spp. with AFLP markers, recommended use of microsatellite markers for such study and considered them more powerful for intra-specific discrimination. In view of the limitations of the molecular markers discussed above, continuous refinements have resulted in more sophisticated markers, like randomly amplified microsatellite polymorphisms (RAMPO) in which genomic DNA is first amplified using arbitrary (RAPD) primers and the amplified products are then electrophoretically separated and dried gel is hybridized with microsatellite oligonucleotide probes. Several advantages of oligonucleotide fingerprinting (Jarvis et al., 1994), RAPD and microsatellite-primed PCR (Weising et al., 1995) are thus combined in this technique. It is fast with high sensitivity, and reveals high level of variability and does not need prior DNA sequence information as is required in RAPD (Richardson et al., 1995). This technique has been successfully employed in the genetic fingerprinting of tomato and other related genotypes (Richardson et al., 1995).

Cytochrome P450 mono-oxygenases are widely found in plants, animals and micro-organisms (Shalk et al., 1999). In higher plants, cytochrome P450s play important role in oxidative detoxification and biosynthesis of secondary metabolites (Ohkawa et al., 1998) and many P450 gene families have been reported in various plant species. Furthermore, P450 genes that have so far been characterized are very diverse and very variable in their gene alignments (Ohkawa et al., 1998). This marker represents a valuable new tool and with only a relatively small number of primers, it is able to analyse both diversity and conservation in plant genomes. Because of significantly high reproducibility of results, these markers have enormous advantages over RAPD and ISSRs and are particularly useful in cases where good sequence information is not available. Similarly, amplified fragment length polymorphism (AFLP) technique developed by Vos et al., (1995) and its modified versions named as SAMPL (selectively amplified microsatellite polymorphic loci) are used to visualize hundreds of amplified DNA restriction fragments simultaneously which are produced by restriction digestion and amplified using PCR, followed fragments by their analysis through autoradiography or use of special fluorescently labelled primers. AFLP enables to estimate diversity at multiple loci within DNA, particularly of species with low genetic base (Campbell et al., 2003 and Després et al., 2003) and without any obligate sequence knowledge (Ridout and Donini, 1999 and Hodkinson et al., 2000) and with high reproducibility (Money et al., 1996). Since its introduction, AFLP and its modified versions (Ranamukhaarachchi et al., 2000) has become prime choice of polymorphism detection and has helped to resolve intra and inter-generic level of polymorphism in many plant species. It has been used in inter-populational studies (Amsellem et al., 2000) and also to establish relationship between different species or sub-species (Kardolus et al., 1998; Koopman et al., 2001; Zhang et al., 2001 and). Studies of Mace et al., (1999) indicated that the AFLP technique is an efficient and effective tool for determining genetic relationships among taxa in Solanaceae. On the basis of AFLP data they proposed a new classification for the tribe Datureae, and placed the arborescent species in a separate genus Brugmansia, and within Datura recognised three sections, namely Stramonium, Dutra and Ceratocaulis. Besides, Datura discolor, previously placed in section Dutra, and was reported to be intermediate between sections Dutra and Stramonium (Mace et al., 1999). Furthermore, AFLP primers were four times more efficient than RAPD primers in their ability to detect polymorphism in Capsicum annum (Paran et al., 1998). While Marcucci-Poltri et al., (1998) used this marker for infra-generic taxonomic studies in Potatoe sub-section of Solanum, Thomas et al., (1995) used it for similar study in tomato. Mace et al., (1999) used AFLP analysis for genetic relationships among cultivated eggplant, Solanum melongena and its wild relatives. Julio et al., (2005) developed AFLP markers linked to three disease resistant varieties in Nicotiana tabacum. Ren and Timko (2001) used AFLP markers for polymorphism analysis and evolutionary relationships among cultivated and wild Nicotiana species. The AFLP data placed all members of series Longipedicellata of genus Solanum into a single clade, sister to $S$. verrucosum and $S$. brachycarpum series Demissa (Kardolus 1998). Spooner et al., (2000) developed AFLP markers for series Longipedicellata which is otherwise difficult to distinguish from members of other series of Solanum. Even AFLP of selected organelles in certain cases has helped to resolve taxonomic riddles. For instance, Komarnyts'kyi and Komarnyts'kyi (2004) using AFLP data of chloroplast DNA, recorded three major clusters within Solanum-Lycopersicon complex and observed that Lycopersicon (sensu lato) species and Solanum lycopersicoides fall in one group. The second cluster included $S$. verrucosum a polyploid species of series Longipedicellata, and all diploid and 
polyploid species native to South America. Two diploid series Pinnatisecta and Bulbocastana were grouped together in another cluster (Komarnyts'kyi and Komarnyts'kyi, 2004). This phylogenetic treatment is strongly supported by morphological and other molecular marker data (Komarnyts'kyi and Komarnyts'kyi, 2004). Negi et al., (2000), on the basis of AFLP data identified two varieties of Withania somnifera in India and also estimated the level of diversity between $W$. somnifera and $W$. coagulans. In recent years, advances in DNA sequencing have contributed significantly to the understanding of the relationships of flowering plants which together with computerized cladistics (Hennig, 1966 and Kitching et al., 1998) has led to the large scale use of a variety of regions of the genome, both from the nucleus and the chloroplast for sequencing. The molecular data so generated have enabled taxonomists to put forth certain audacious taxonomic conclusions. Systematic studies in the Solanaceae have benefited greatly from these advances, with phylogenetic studies having been published for a variety of genera and species groups (Mione et al., 1994; Axelius, 1996; Bohs, 2001) and the resolution of the relationships of several enigmatic genera, like Duckeodendron, whose inclusion in the family has been the subject of much debate (D'Arcy, 1991). For example, tomatoes previously recognized as a separate genus called Lycopersicon and tree tomatoes (ex Cyphomandra) are deeply nested in the genus Solanum (Bohs, 2005; Bohs and Olmstead). Molecular data have resolved enigma of kinship of Solanaceae, and now it is established that its closest sister taxon is Convolvulaceae (Olmstead et al., 1992). The disagreement that still exists about the utility of classifications largely based on DNA sequence data would disappear as more gene sequences from both chloroplast and nucleus become available. In tune with this requirement, ribosomal DNA sequence has been extensively used for diversity analysis, species identification and phylogenetic analysis. In fact, phylogenetic analysis based on $5 \mathrm{~S}$ ribosomal RNA (rRNA) genes (about $120 \mathrm{bp}$ in length) have long been used to elucidate the origin and evolution of a number of organisms. Matyášek et al., (2003) demonstrated the role of $5 \mathrm{~S}$ ribosomal DNA (rDNA) in the taxonomy of Nicotiana and phylogenetic reconstruction of species and relationships, particularly, in section Tomentosae. This study also indicated that Nicotiana glutinosa diverged early from the section Tomentosae. Likewise, $18 \mathrm{~S}$ ribosomal RNA genes, about $2 \mathrm{~kb}$ in size, have been widely sequenced for reconstruction of phylogeny at higher taxonomic levels in plants, including species of Solanaceae (Kiss et al., 1989 and Chaw et al., 1997). In several instances, $18 \mathrm{~S}$ rDNA sequence data have provided a critical test of phylogenetic inferences obtained from other data (Kron, 1996). In certain cases $18 \mathrm{~S}$ rDNA sequence data sufficiently resolved infra-familial and infrageneric taxonomic puzzles. Harding and Millam
(1999) exploited ribosomal RNA genes as markers to identify somatic hybrids between Solanum tuberosum cv. Brodick and wild diploid species, like S. megistacrolobum, S. sanctae-rosae and S. sparsipilum. The markers revealed some intermediate ribosomal RNA gene profiles indicative of hybrid nature of certain species whereas others were characteristic of S. tuberosum cv. Brodick. This evidence is suggestive of somatic exchange / re-arrangement between the nucleolar organizer region (NOR) region of $S$. sanctae-rosae and S. tuberosum cv. Brodick. Ribosomal RNA gene copy number analysis of the somatic hybrids did not reveal hexaploid values suggesting that these products are not symmetric hybrids derived from the parental diploid and tetraploid plants of S. sparsipilum (Harding and Millam, 1999). Komarova et al., (2004) studied organization of rDNA in allopolyploids of Solanum for taxonomic elucidation. Similarly, Borisjuk et al., (1997) analysed rDNA including intergenic spacer of Nicotiana for taxonomic studies. Levin et al., (2005) used sequence of four genes for studying evolutionary relationships in Solanum section Acanthophora. The spacers, particularly, flanking the $5.8 \mathrm{~S}$ ribosomal gene find their use for such purposes within and among closely related genera (Baldwin, 1992; McBreen et al., 2003; Ahmad et al., 2006 and Verma et al., 2005). Ryzhova et al., (2002) reported that two types of rDNA internal transcribed spacers (ITSs) in Capsicum were helpful in resolving infra-generic relationships within the genus. Molecular data from the nuclear ITS region established that Normania and Triguera are nested within the large genus Solanum, where they together form a well-supported clade (Bohs and Olmstead, 2001). However, the relationship of this clade to other Solanum subgroups is not clear. The study necessitated transfer of Normania and Triguera epithets to Solanum. The molecular data also confirmed that the species of Solanum endemic to Micronesia belonged to two distinct clades, each showing an independent evolution of heteromorphic anthers. Anderson and Jansen et al., (1998) evaluated relationships of Solanum muricatum based on ITS sequence data.

Intergenic spacer (IGS) i.e. the spacer between $18 \mathrm{~S}$ and $28 \mathrm{~S}$ ribosomal genes particularly its external transcribed spacer (ETS) region is another suitable marker for diversity analysis. Borisjuk et al., (1997) found unique sequence in the central part of the IGS in the genus Nicotiana tabacum, which distinguished it from Solanum tuberosum and Solanum lycopersicon (syn. Lycopersicon esculentum). The IGS rDNA, in latter two species, exhibited similar length and general architecture with high level of similarity $(86 \%$ and $86.5 \%$, respectively) in the AT-rich domain containing the transcription initiation site (TIS) and the region approximately $800 \mathrm{bp}$ upstream of the $18 \mathrm{~S}$ rRNA gene (Borisjuk and Hemleben, 1993). However, as compared to tomato (Perry and Palukaitis, 1990) repeated elements down-stream of the putative TIS are absent in 
potato, which is compensated by sub-repeats upstream of the TIS (Borisjuk and Hemleben, 1993). Santiago-Valentini and Olmstead (2003) used DNA sequences of the intergenic spacer along with ITS for phylogenetic analysis and elucidation of the evolutionary relationships of Coeloneurum, Espadaea and Henoonia with Goetzea and other major lineages of the Solanaceae. The results inferred that these genera comprise a group together with Metternichia and Duckeodendron in a clade within the Solanaceae, pointing towards a broader circumscription of the sub-family Goetzeoideae. Matyášek et al., (2003) demonstrated the presence of the GC-rich subregion in non-transcribed spacer of IGS rDNA in a range of Nicotiana species, which was absent in $N$. sylvestris, $N$. longiflora and two closely related genera, Petunia and Solanum. The sequence data suggested that this sub-region of the non-transcribed spacers (NTS) is likely to have evolved within the genus Nicotiana. The absence of the sub-region in $N$. sylvestris and $N$. longiflora is likely to have arisen by a deletion event in the evolution of section Alatae. Volkov et al., (1996) compared external transcribed spacer (ETS) of two close diploid relatives of the allotetraploid Nicotiana tabacum, N. sylvestris (subg. Petunioides) and N. tomentosiformis (subg. Nicotiana) and other species of Solanaceae and obtained sequence differences in ETS region between these different species. Characteristically there were 5 sub-repeats in $N$. sylvestris and 10 sub-repeats in $N$. tomentosiformis in the ETS region. The portion of ETS adjacent to $18 \mathrm{~S}$ rRNA gene, exhibited much higher similarities between species, not only among $N$. sylvestris and $N$. tomentosiformis but also within more distantly related Solanaceae. At the $5^{\prime}$ end of the ETS in the two Nicotiana species studied, were three copies of highly divergent sub-repeats (Volkov et al., 1996). At lower taxonomic levels, 3' end of ETS ( $3^{\prime}$-ETS) has been used as a useful locus (King et al., 1993 and Volkov et al., 1996) and has been successfully used for phylogenetic reconstruction of several genera of Solanaceae (Bena et al., 1998; Baldwin and Markos, 1998 and Linder et al., 2000).Volkov et al., (1996) studied molecular organization and evolution of the ETS region in two diploid relatives of Nicotiana tabacum. Volkov et al., (2003) estimated evolutionary relationships of section Petota of genus Solanum from the sequence data of $5^{\prime}$ of external transcribed spacer region of rDNA. They resolved nature of ancestral organization of ETS in non-tuber bearing species of series Eutuberosa, Bulbocastana, Pinnatisecta and Poladenia and in Solanum dulcamera. The study maintained that species of $S$. commersonii represents a sister taxon for all species with rotate corolla within the section Petota and series Circaeifolia diverged very earlier within the section.

DNA sequence data of organelles other than nucleus, particularly of chloroplast genes, has proved of immense value in phylogenetic studies (Ritland and Clegg, 1987; Clegg, 1993 and Sakata and Lester, 1997). Though large but of manageable size relative to animal mitochondrial DNA, lack of independently evolving duplicated genes (Olmstead and Palmer, 1994) and intron free genes have made cpDNA ideal for phylogenetic study. This potential is borne out by extensive use of cpDNA-encoded genes to study plant phylogeny. Besides, there are other reasons for this focus on a single organelle that by itself accounts for less than $0.1 \%$ of the genetic complement of plants. One important reason for extensive use of cpDNA in systematic studies is a conservative rate of nucleotide substitution (Palmer, 1991), which makes it ideal for the study of plant phylogeny and for elucidating relationships at or beyond family level (Olmstead and Palmer, 1994). Besides, plastid sequences are less plagued by problems of among-site and amonglineage rate heterogeneity, which have often compromised the accuracy of phylogenetic inference in animals. Comparative study of cpDNA is particularly relevant to Solanaceae because chloroplast genome of Nicotiana tabacum is completely sequenced which could serve as a reference genome within the family. Many of the systematic advances made on the basis of extensive cpDNA studies have been reviewed by several workers (Palmer et al., 1988; Clegg, 1993; Doyle, 1993; Systma and Hahn, 1994). A perusal of this information in the context of Solanaceae (Bradford and Barnes, 2001) reveals that the DNA sequence data of cpDNA have helped to resolve some longstanding problems in Solanaceae systematics, like phylogenetic relationships in Solanum (Palmer and Zamir, 1982; Spooner et al., 1993), Nicotiana (Kung et al., 1982 and Olmstead and Palmer, 1991), Jaltomata (Mione et al., 1994), Physalis and related genera (Mione et al., 1994). On the basis of molecular phylogeny of chloroplast and mitochondrial genes, Kulcheski et al., (2006) separated the genus Petunia into two complexes while Livingstone et al., (1999) showed that Capsicum species differed by at least one reciprocal translocation. Rodriguez and Spooner (1997) and Bohs and Olmstead (1998) used chloroplast DNA study for taxonomic analysis of Solanum. Mione et al., (1994) and Olmstead and Palmer (1997) explored systematic implications of chloroplast DNA variations in taxonomy of Jaltomata and Solanum, respectively. Similarly Spooner et al., (1993) used sequence data of chloroplast DNA as an evidence for interpreting interrelationships of tomatoes and potatoes. Sequence data of two chloroplast genes viz. $r b c L$ (ribulose 1, 5bisphosphate carboxylase / oxygenase large subunit) and atpB (ATP synthase as $\beta$-subunit) have been most extensively used for taxonomic resolution of plant species (Chase and Cox, 1998; Hoot and Douglas, 1998). Both the genes are located in the plastid genome separated by a small spacer region (Savolainen et al., 1997). Though different evolutionary constraints are likely to be involved because the two genes code for distinct 
enzymatic functions but at the same time being part of the same non-recombining piece of DNA, they are believed to share the same evolutionary history. Although the gene sequence data of $r b c L$ and atpB is more suitable to infer relationships at family level but in certain cases it has served the purpose at generic or infra-generic level. Fukuda et al., (2001) examined evolutionary relationships within species of Lycium using chloroplast DNA sequence data from matK and $t r n$ T-trn F loci. Olmstead and Sweere (1994) found molecular data of $n d b \mathrm{~F}$ (a chloroplast gene) and $r b c L$ congruent with perceived phylogeny of Solanaceae but found it conflicting upon its extension to sub-family level. On the basis of sequence data of chloroplast genome, Bouchetia, Hunzikeria, and Nierembergia were found to be of monophyletic origin. The $r b c L$ and $n d b F$ sequence data suggested that Solanoideae and Nicotianoideae (including Nicotiana and the Anthocercideae) represent a monophyletic group and together form the "x = 12" complex (Olmstead et al., 1998). Within the later, tribe Nicotianeae is sister to tribe Anthocercideae. Within Solanoideae, basal branch consists of tribes Hyoscyameae, Lycieae, Nolaneae and Jaborosae; with Hyoscyameae as a sister group to the clade composed of other three tribes. The second basal branch in the Solanoideae consists of Mandragoreae and Solandreae. The data also supported weak unification of Nicandra and Exodeconus as suggested by D'Arcy (1991). The chloroplast sequence data of $n d b \mathrm{~F}$ and $r b c L$ supported opinion of Hunziker (1979) and D'Arcy (1991) that Datureae form a sister group to a large clade comprising most of the traditional Solaneae. The cpDNA results provided the first evidence for dividing the traditional Solaneae along phylogenetic lines. Olmstead et al., (1998) suggested a classification that included a much reduced Solaneae, including Solanum (with Lycopersicon and Cyphomandra) and Jaltomata, a new tribe Capsiceae and a new large tribe Physaleae. While the cpDNA study showed that Solanum etuberosum and $S$. palustre are more similar to each other than to $S$. fernanderianum (Spooner et al., 1996). On the basis of sequence data of $n d b \mathrm{~F}$, Bohs and Olmstead (1997) and Bohs (2005) identified major clades within Solanum. Santiago-Valentini and Olmstead (2003) used DNA sequences of the chloroplast genes $n d b \mathrm{~F}$, $r b c L$ and $t r n L-t r n F$ intron, in addition to IGS and ITS for phylogenetic analysis among solanaceous genera, including Coeloneurum, Espadaea, Henoonia, Goetzea and other major lineages of Solanaceae. The DNA sequences pointed out that these genera group together with Metternichia and Duckeodendron in a clade within the Solanaceae, pointing towards a broader circumscription of sub-family Goetzeoideae. Combined data of $r b c L$ and $n d h \mathrm{~F}$ yielded a more fully resolved tree of Solanaceae (Olmstead and Sweare, 1994). The "x = 12" complex forming a single clade was also well supported by the study of Olmstead and Sweare (1994). Levin and Miller (2005) using DNA sequence data from nuclear granule-bound starch synthase gene (GBSSI, waxy) and the chloroplast region trnL-trnF, inferred phylogenetic relationships among Lycium, Grabowskia, and the monotypic genus Phrodus microphyllus. Tribe Lycieae was strongly supported as of monophyletic origin, but Lycium likely included both Grabowskia and Phrodus. The results also suggested a single dispersal event from the Americas to the Old World, and frequent dispersal between North and South America (Levin and Miller, 2005). Walsh and Hoot (2001) found sequence data of atpB-rbcL spacer region and nuclear waxy introns helpful in resolving phylogenetic relationships of Capsicum. Similar was the corollary of Bohs and Olmstead (1997) for Solanum based on $n d h \mathrm{~F}$ and other chloroplast sequence data. With molecular data from the nuclear granule-bound starch synthase gene (GBSSI or waxy) and the chloroplast trn $\mathrm{T}-\mathrm{F}$ region, (Anderson et al., 2006) confirmed the hypothesis that Solanum vespertilio and S. lidii are phylogenetically associated with Solanum lineages from Africa, rather than with previously suggested Mexican species. In recent years, molecular marker technology in higher plants has witnessed a shift from the so-called random DNA markers (RDMs), developed in the past arbitrarily from genomic DNA and cDNA, to the molecular markers representing the transcriptome and the other coding sequences (Gupta and Rustgi, 2004). These markers have been described as gene targeted markers (GTMs). Another specific class of markers includes the socalled functional markers (FMs), which are supposed to have a cause and effect relationship with the traits of interest. Markers of different classes are derived from cDNA clones, expressed sequence tags (ESTs), gene sequences and the unique (coding) sequences obtained through methyl filtration or genome normalization (high $C_{0} t$ fraction) from genomic DNA libraries. Similarly RFLPs, SSRs, AFLPs, SNPs and many more novel markers are being developed from the transcriptome (cDNA clones and EST databases) and specific genes (Gupta and Rustgi, 2004). These novel markers include expressed sequence tag polymorphisms (ESTPs), conserved orthologue set (COS) markers, amplified consensus genetic markers (ACGMs), gene specific tags (GSTs), resistance gene analogues (RGAs) and exonretrotransposon amplification polymorphism (ERAP). Use of these markers is being extended to Solanaceae also (Gupta and Rustgi, 2004). Sequence data of $\beta$-tubulin, salicylic acid methyltransferase, SNPs etc is being included with this purpose. Using cDNA sequences of SAMT (salicylic acid methyltransferase) gene in Solanaceae, Martins and Barkman (2005) obtained results mostly congruent with previous cpDNA estimates. The relationships observed with SAMT data included Schizanthus as a sister taxon to the rest of the family. The second branch was Schwenckioideae + Cestroideae. The 
final two lineages were Petunioideae, sister to the ' $\mathrm{X}$ $=12$ ' complex, which included Nicotianoideae plus Solanoideae. However, clades of Nicandra and Exodeconus were not treated as sister taxa; rather, Exodeconus was near the base of Solanoideae while Nicandra appeared to belong to a lineage that included Physalis, Capsicum, Solanum, and Datura.

The use of sequence data in phylogenetic elucidation is restricted not only to coding regions and their spacers but some scientists advocated utilizing alignable sequence tracts from other regions. Kress et al., (2005) used DNA bar coding as a marker. They have recommended using sequence data of various loci, particularly, nuclear rDNA for such purposes in flowering plants. Such 'DNA barcodes' showed promise in providing a practical, standardized, species-level identification tool that can be used for biodiversity assessment and analysis. Despite the controversy over the value of DNA bar coding, largely because of the perception that this new identification method would diminish rather than enhance traditional morphology-based taxonomy, there is a support of bar coding as a species identification process from various corners (Besansky et al., 2003; Hebert et al., 2003 and Janzen, 2004), who stressed on its utility as a powerful tool for identifying specimens.

\section{Conclusion and future prospects}

Solanaceae belongs to that group of families, which are included in almost all angiosperm classifications indicating naturalness of the family. The family being one of the most evolutionarily successful and advanced taxa shows astonishing level of diversity reflected in the form of various types of adaptations (Cocucci, 1999; Raguso et al., 2003; Sazima et al., 2003 and Kaczorowski et al., 2005). The high level of diversity within the family in addition to other unusual features have reflected in poor understanding of its phylogenetics. Fossil record of angiosperms particularly of Solanaceae (Collinson et al., 1993) is very meager and relatively recent, so use of morphology and other conventional characters (Scotland et al., 2003) is not convincing in revealing true phylogeny of the family. This all has necessitated using alternative marker types in phylogenetic analysis of the family. Since advent of molecular biology molecular markers have been constantly refined to serve the purpose. Genetic diversity studies through molecular markers will help to solve the taxonomic ambiguities of several genera further the study will unfold the diversity at genetic level which will be helpful in crop genetic studies and breeding programmes.

\section{References}

1. Ahmad SM, Verma V, Qazi PH, Ganaie MM, Bakshi SK and Qazi GN. "Molecular phylogeny in Indian Tinospora species by DNA based molecular markers. Plant Systematics and Evolution." 256 (2006): 75-87.
2. Aagaard GE, Krutovskii KV and Strauss SH. "RAPD markers of mitochondrial origin exhibiting lower population diversity and higher differentiation than RAPDs of nuclear origin in Douglas fir. Molecular Ecology.” 7 (1998): 801-812.

3. Amsellem LJ, Noyer L, Le Bourgeois T and Hossaert-Mckey M. "Comparison of genetic diversity of the invasive weed Rubus alceifolius Poir. (Rosaceae) in its native range and in areas of introduction, using amplified fragment length polymorphism (AFLP) markers. Molecular Ecology." 9 (2000): 443-455.

4. Anderson GJ, Bernardello G, Bohs L, Weese T and SantosGuerra A. "Phylogeny and biogeography of the Canarian Solanum vespertilio and $S$. lidii (Solanaceae). Anales del Jardin Botánico de Madrid." 63 (2006): 159-167.

5. Ando, T., Kokubun H, Watanabe H, Tanaka N, Yukawa T, Hashimoto G, Hashimoto E, Marchesi E, Suarez E and Basualdo IL. "Phylogenetic analysis of Petunia sensu Jussieu (Solanaceae) using chloroplast DNA RFLP.” Annals of Botany. 96 (2005): 289-297.

6. Angiosperm Phylogeny Group "An update of the Angiosperm Phylogeny Group classification for the orders and families of flowering plants: APG III", Botanical Journal of the Linnean Society 161 (2009): 105- 121 .

7. Atienzar F, Evenden A, Jha A., Savva D and Depledge M. "Optimized RAPD analysis generates high quality genomic DNA profiles at high annealing temperatures." BioTechniques. 28 (2000): 52-54.

8. Axelius B. "The phylogenetic relationships of the physaloid genera (Solanaceae) based on morphological data." American Journal of Botany. 83 (1996): 118-124.

9. Baldwin BG. "Phylogenetic utility of internal transcribed spacer of nuclear ribosomal DNA in plants: An example from the Compositae." Molecular Phylogenetics and Evolution. 1 (1992): 3-16.

10. Baldwin BG and Markos S. "Phylogenetic utility of the external transcribed spacer (ETS) of 18S-26S rDNA: Congruence of ETS and ITS trees of Calycadenia (Compositae)." Molecular Phylogenetics and Evolution. 10 (1998): 449-463.

11. Bauhin C. Pinax Theatri Botanici .Basel. 1623

12. Bena G, Jubier MF, Olivieri I and Lejeune B. "Ribosomal external and internal transcribed spacers: Combined use in the phylogenetic analysis of Medicago (Leguminosae)." Journal of Molecular Evolution. 46 (1998.): 299-306.

13. Bentham, G. and Hooker J D. Genera Plantarum. L. Reeve \& Co., London. 1862-1883.

14. Besansky NJ, Severson DW and Ferdig MT. "DNA bar coding of parasites and invertebrate disease vectors: What you don't know can hurt you." Trends in Parasitology. 19 (2003): 545-546.

15. Bindler G, Van der Hoeven R, Gunduz I, Plieske J, Ganal M, Rossi L, Gadani F and Donini F. "A microsatellite marker based linkage map of tobacco." Theoretical and Applied Genetics. 114 (2007): 341-349.

16. Bohs L. "Insights into the Witheringia solanacea (Solanaceae) complex in Costa Rica. II. Insect visitors and pollination biology of $W$. asterotricha and W. meiantha. Biotropica." 32 (2000.): 80-89.

17. Bohs L. "A revision of Solanum section Cyphomandropsis (Solanaceae)." Systematic Botany Monographs. 61 (2001): 1-85.

18. Bohs, L. "Major clades in Solanum based on $n d b F$ sequence data. In: R. C. Keating, V. C. Hollowell and T. B. Croat (eds.). A Festschrift for William G. D'Arcy: The Legacy of a Taxonomist." Missouri Botanical Garden, St. Louis (2005): 27-49.

19. Bohs L. and Olmstead R.G. "Phylogenetic relationships in Solanum (Solanaceae) based on $n d h F$ sequences." Systematic Botany. 22 (1997): 5-17. 
20. Bohs L and Olmstead RG. "A reassessment of Normania and Triguera (Solanaceae).' Plant Systematics and Evolution. 228 (2001): 33-48.

21. Borisjuk $\mathrm{N}$ and Hemleben V. "Nucleotide sequence of the potato rDNA intergenic spacer." Plant Molecular Biology. 21 (1993): 381-384.

22. Borisjuk NV, Davidjuk YM, Kostishin SS, Miroshnichenco GP, Velasco R,Hemleben V and Volkov RA. „Structural analysis of rDNA in the genus Nicotiana." Plant Molecular Biology. 35 (1997): 655-660.

23. Bornet, B. and Branchard M. "Non-anchored inter simple sequence repeat (ISSR) markers: Reproducible and specific tools for genome fingerprinting." Plant Molecular Biology Reporter.19 (2001): 209-215.

24. Bradford JC and Barnes RW. "Phylogenetics and classification of Cunoniaceae (Oxalidales) using chloroplast DNA sequences and morphology." Systematic Botany. 26 (2001.): 354-385.

25. Brown, R. "Prodromus Florae Novae Hollandiae." Richard Taylor, London. 1810.

26. Caetano-Anolles G., Bassam BJ and Gresshof PM. "DNA amplification fingerprinting using very short arbitrary oligonucleotides." Biotechnology. (1991.): 553-557.

27. Campbell D, Duchense P and Bernautchez L. "AFLP utility for population assignment studies: Analytical assignment and empirical comparison with microsatellites." Molecular Ecology. 12 (2003): 1979-1991.

28. Chase, MW and Cox AV. "Gene sequences, collaboration and analysis of large data sets." Australian Systematic Botany. 11 (1998): 215-229.

29. Chaw SM., Zharkikh A, Sung HM, Lau TC and Li WH. "Molecular phylogeny of extant gymnosperms and seed plant evolution: Analysis of nuclear 18S rRNA sequences." Molecular Biology and Evolution. 14 (1997.): 56-68.

30. Clegg MT. "Chloroplast gene sequences and the study of plant evolution." Proceedings of National Academy of Sciences, US A. 90 (1993): 363-367.

31. Cocucci AA. "Evolutionary radiation in neotropical Solanaceae. [In: M. Nee, D. E. Symon, R. N. Lester and J. P. Jessop (eds.) Solanaceae IV: Advances in Biology and Utilization. Royal Botanic Gardens, Kew, UK.] (1999): 9-22.

32. Collinson ME., Boulter MC and Holmes PL. "Magnoliophyta ('Angiospermae'). [In: M. J. Benton [eds.]. The Fossil Record." Chapman and Hall, London, UK] 2 (1993): 809-849.

33. Cronquist A. "An Integrated System of Classification of Flowering Plants." Columbia University Press, New York, USA. 1981.

34. D'Arcy WD. “The classification of the Solanaceae. [In: Hawkes JG, Lester RN and Skelding AD (eds.). The Biology and Taxonomy of the Solanaceae." Academic Press: London] (1979): 3-47.

35. Demeke T, Kawchuk LM and Lynch DR. "Identification of potato cultivars and clonal variants by random amplified polymorphic DNA analysis." American Potato Journal. 70 (1993): 561-570.

36. Doyle JJ. "DNA, phylogeny and the flowering of plant systematics.” BioScience. 43 (1993): 380-389.

37. Engler A and Prantl K. "Die Naturlichen Pflanžnfamilien. Leipzig." 23 vols. 1887-1915.

38. Fukuda T, Yokoyama $\mathrm{J}$ and H. Ohashi H. "Phylogeny and biogeography of the genus Lycium (Solanaceae): Inferences from chloroplast DNA sequences." Molecular Phylogenetics and Evolution. 19 (2001): 246-58

39. Gupta PK and Rustgi S. "Molecular markers from the transcribed / expressed region of the genome in higher plants." Functional and Integrative Genomics. 4 (2004): 139-162.
40. Guzmán, FA, Ayala H, Azurdia C, Duque MC and de Vicente MC. "AFLP assessment of genetic diversity of Capsicum. Genetic resources in Guatemala home gardens as an option for conservation." Crop Science. 45 (2005): 363-370.

41. Harding K. and Millam S. "Analysis of chromatin, nuclear DNA and organelle composition in somatic hybrids between Solanum tuberosum and Solanum sanctae-rosae." Theoretical and Applied Genetics. 101 (1999): 939-947.

42. Hebert PDN, Cywinska A, Ball SL and De Waard JR "Biological identifications through DNA barcodes." Proceedings of Royal Society for Botany. 270 (2003): 313-321.

43. Heiser, CB Jr. "Nightshades: The Paradoxical Plants. Freeman, WH San Francisco, CA. 1969.

44. Hennig, W. 1966. Phylogenetic Systematics. Translated by D. D Davis and R. Zangerl. University of Illinois Press, Urbana.

45. Hodkinson TR., Renvoize SA, Chonghaile GN, Stapleton C and Chase MW. "A comparison of ITS nuclear rDNA sequence data and AFLP markers for phylogenetic studies in Phyllostachys (Bambusoideae, Poaceae)." Journal of Plant Research. 113 (2000): 259-269.

46. Hoot SB and Douglas AW. "Phylogeny of the Proteaceae based on atpB and atpB-rbcL intergenic spacer region sequences." Australian Systematic Botany. 11 (1998): 301-320.

47. Hunziker AT. "South American Solanaceae: A synoptic survey. [In: J. Hawkes G, Lester RN and Skelding AD (eds.). The Biolog and Taxonomy of the Solanaceae. Academic Press, London, UK] (1979): 49-85.

48. Hutchinson J. "The Families of Flowering Plants. $3^{\text {rd }}$ edition. Oxford University Press. 1973.

49. Janzen DH "Now Is The Time. Philos Trans" Royal Society London B Biological Science. 359 (2004): 731-732.

50. Jarvis P, Lister C, Szabo V and Dean C. "Integration of CAPs markers into the RFLP map generated using recombinant inbred lines of Arabidopsis thaliana." Plant Molecular Biology. 24 (1994): 685-687.

51. Joshi SP, Ranjekar PK and Gupta.VS. "Molecular markers in plant genome analysis." Current Science. 77 (1999): 230-240.

52. Julio E, Verrier JL and de Borne FD 2005. Development of SCAR markers linked to three disease resistances based on AFLP within Nicotiana tabacum L. Theoretical and Applied Genetics. 112 (2005): 335-346

53. Junli Z, Zhengfeng W, Mingguang L and Bosun W. "Molecular markers and their application in plant population research". Yingyong Shengtai Xuebao. 11 (2000): 631-636.

54. Jussieu A L. de. "Genera Plantarum.” Paris. 1789

55. Kaczorowski RL, Kaczorowski, Gardener MC and Holtsford TP. "Nectar traits in Nicotiana section Alatae (Solanaceae) in relation to floral traits, pollinators and mating system." American Journal of Botany. 92 (2005): 1270-1283.

56. Kardolus JP, van Eck HJ and van den Berg RG. "The potentia of AFLPs in biosystematics: A first application in Solanum taxonomy (Solanaceae). Plant Systematics and Evolution. 210 (1998): 87-103.

57. Karihaloo JL, Brauner S and Gottlieb LD. "Random amplified polymorphic DNA variation in the eggplant, Solanum melonogena L. (Solanaceae)." Theoretical and Applied Genetics. 90 (1995): $767-$ 770

58. Karp A, Kresovich S, Bhat KV, Ayad WG and Hodgkin T "Molecular Tools in Plant Genetic Resources Conservation: A Guide to the Tecbnologies." International Plant Genetic Resources Institute, Rome. 1997. 
59. Kelly AJ and Willis JH. "Polymorphic microsatellite loci in Mimulus guttatus and related species." Molecular Ecology. 7 (1998): 769-774.

60. King K., Torres RA, Zentgraf U. and Hemleben.V. "Molecular evolution of the intergenic spacer in the nuclear ribosomal RNA genes of Cucurbitaceae." Journal of Molecular Evolution. 36: (1994) $144-152$.

61. Kiss T, Szkukalek A and Solymosy F. "Nucleotide sequence of a 17S (18S) rRNA gene from tomato." Nucleic Acids Research. 17 (1989): 21-27.

62. Kitching IJ, Forey PL, Humphries CJ and Williams DM "Cladistics: The Theory and Practice of Parsimony Analysis." 2nd edn. Oxford University Press, Oxford. 1998.

63. Knapp, S. "Is morphology dead in Solanum taxonomy? [In: van der Werden G, Barendse G and van den Berg R (eds.). Solanaceae $V$. University of Nijmegen, the Netherlands.] 2001: 23-38.

64. Knapp S, Bohs L, Nee M and Spooner M. "Solanaceae- a model for linking genomics with biodiversity. Comparative and Functional Genomics. 5 (2004): 285-291.

65. Kochieva EZ, Ryzhova NN, Khrapalova IA and Pukhal'skii VA. "Genetic diversity and phylogenetic relationships of the genus Lycopersicon (Tourn.) Mill. as revealed by inter-simple sequence repeat (ISSR) analysis." Genetika. 38 (2002b): 1133-1142.

66. Kochieva E Z, Ryzhova NN, Khrapalova IA and Pukhalskyi VA. "Using RAPD for estimating genetic polymorphism in and phylogenetic relationships among species of the genus Lycopersicon (Tourn.) Mill.” Russian Journal of Genetics. 38 (2002a): 1104-1108.

67. Komarnyts'kyi SI and Komarnyts KI. "Genetic variability among Solanum and Lycopersicon species revealed by amplified fragment restriction polymorphism analysis of chloroplast DNA." Tsitol Genetics. 38 (2004): 9-15.

68. Komarova N, Grabe T, Huigen D, Hemleben V and Volkov R. "Organization, differential expression and methylation of rDNA in artificial Solanum allopolyploids." Plant Molecular Biology. 56 (2204): 439-463

69. Koniecyzn A and Ausubel FM. "A procedure for mapping Arabidopsis mutations using co-dominant ecotype-specific PCR based markers." Plant Journal. 4 (1993): 403-410.

70. Koopman WJM, Zevenbergen MJ and Van den Berg RG "Species relationships in Lactuca s. I. (Lactuceae, Asteraceae) inferred from AFLP fingerprints." American Journal of Botany. 88 (2001): 1881-1887.

71. Kress JW, Wurdack KJ, Zimmer EA, Weigt LA and Janzen DH. "Use of DNA barcodes to identify flowering plants." Proceedings of National Academy of Sciences US A. 102 (2005): 8369-8374.

72. Kron K. "Phylogenetic relationships of Empetraceae, Epacridaceae and Ericaceae: Evidence from nuclear ribosomal 18S sequence data." Annals of Botany. 77 (1996): 293-303.

73. Kubis SE, T. Schmidt T and Heslop-Harrison JS. "Repetitive DNA elements as a major component of plant genomes." Annals of Botany. 82 (1998): 45-55.

74. Kulcheski FR., Muschner VC, Lorenz-Lemke AP, Stehman JR, Bonatto SL, Salzano FM and Freitas LB. "Molecula phylogenetic analysis of Petunia Juss. (Solanaceae)." Genetica. 126 (2006.): 3-14.

75. Kumar LD, Kathirvel M, Rao GV and Nagaraju J. "DNA profiling of disputed chilli samples (Capsicum annum) using ISSRPCR and FISSR-PCR marker assays." Forensic Science International. 116 (2001): 63-68.

76. Kung SD., Zhu YS and Chen K. "Nicotiana chloroplast genome III. Chloroplast DNA evolution." Theoretical and Applied Genetics. 61 (1982): 73-79.
77. Levin RA and Miller JS. "Relationships within tribe Lycieae (Solanaceae): Paraphyly of Lycium and multiple origins of gender dimorphism." American Journal of Botany. 92 (2005): 2044-2053.

78. Levin R., Watson AK and Bohs L. "A four-gene study of evolutionary relationships in Solanum section Acanthophora." American Journal of Botany 92 (2005): 603-612.

79. Li A and Ge S. "Genetic variation and clonal diversity of Psammocbloa villosa (Poaceae) detected by ISSR markers." Annals of Botany. 87 (2001.): 585-590.

80. Linde, CR., Goertzen LR, Heuvel BV, Francisco-Ortega J and. Jansen RK. "The complete external transcribed spacer of 18S$28 \mathrm{~S}$ rDNA: Amplification and phylogenetic utility at low taxonomic levels in Asteraceae and closely allied families." Molecular Phylogenetics and Evolution. 14 (2000): 285-303.

81. Linnaeus C., "Species Plantarum," 2 vols. Stockholm1753.

82. Livingstone KD, Lacksney VK, Blauth J, Peleman J and Jahn MM. "Genetic mapping in Capsicum and genome structure in the Solanaceae. Plant \& Animal Genome VII Conference.” San Diego, CA, January 17-21. 1999.

83. Mace ES. Gebhardt CG and Lester RN. AFLP analysis of genetic relationships in the tribe Datureae (Solanaceae). Theoretical and Applied Genetics. (1999) $634-641$

84. Marcucci-Poltri, S., M. C. Martinez and S. Hopp. Genetic relationships in the genus Solanum subsection Potato using RFLP, AFLP and SSR markers (Abstr.). [In: VI Plant and Animal Genome Meeting. San Diego, CA.]. 1998.

85. Marienfeld J, Unseld M and Brennicke A. "The mitochondrial genome of Arabidopsis is composed of both native and immigrant information." Trends in Plant Science. 4 (1999): 495 502

86. Martins TR and Barkman TJ. "Reconstruction of Solanaceae phylogeny using the nuclear gene SAMT." Systematic Botany. 30(2005): 435-447.

87. Matyasek R, Lim KY, Kovarik A, Leitch AR "Ribosomal DNA evolution and gene conversion in Nicotiana rustica." Heredity. 91 (2003): 268-275

88. McBreen K, Lockhart PJ and McLenachan PA (2003). "The use of molecular techniques to resolve relationships among traditional weaving cultivars of Phormium." New Zealand Journal of Botany. 41 (2003): 301-310.

89. Mione T, Olmstead RG, Jansen RK and Anderson GJ. "Systematic implications of chloroplast DNA variation in Jaltomata and selected physaloid genera (Solanaceae)." American Journal of Botany. 81 (1994): 912-918.

90. Money T, Reader S, Qu LJ, Dunford RP and Moore G. "AFLPbased mRNA fingerprinting." Nucleic Acids Research. 24 (1996): 2616-2617.

91. Negi M S, Singh A and Laxmikumaran M. "Genetic variation and relationship among and within Withania species as revealed by AFLP markers." Genome. 43(2000): 975-980.

92. Ohkawa $\mathrm{H}$, Imaishi $\mathrm{H}$, Shiota $\mathrm{N}$, Yamada $\mathrm{T}$, Inui $\mathrm{H}$ and Ohkawa Y. "Molecular mechanisms of herbicide resistance with special emphasis on cytochrome P450 mono-oxigenases." Plant Biotechnology. 15 (1998): 173-178.

93. Olmstead RG and Sweere JA. "Combining data in phylogenetic systematics: An empirical approach using three molecular dat sets in the Solanaceae." Systematic Biology. 43 (1994): 467-481.

94. Olmstead, R. G. and P. A. Reeves. 1995. Polyphyletic origin of the Scrophulariaceae: Evidence from $r b c L$ and $n d b F$ sequences. Annuals of Missouri Botanical Garden. 82: 176-193.

95. Olmstead RG. Michaels, HJ Scott KM and Palmer JD. 'Monophyly of the Asteridae and identification of their major lineages inferred from DNA sequences of $r b c L$. Annals of Missour Botanical Garden. 79 (1992): 249-265. 
96. Olmstead RG and Palmer JD. "Implications for the phylogeny, classification, and biogeography of Solanum from cpDNA restriction site variation. Sysematic Botany." 22 (1997): 19-29.

97. Olmstead RG and Palmer JD. "Chloroplast DNA systematics: A review of methods and data analysis." American Journal of Botany. 81(1994.): 1205-1224.

98. Palmer JD. "Plastid chromosomes: Structure and evolution. [In: L. Bogorad and I. K. Vasil (eds.). The Molecular Biology of Plastids (Cell Culture and Somatic Cell Genetics of Plants)." Academic Press, San Diego]. (1991)7a: 5-53.

99. Palmer JD and Zamir D. "Chloroplast DNA evolution and phylogenetic relationships in Lycopersicon." Proceedings of the National Academy of Sciences, US A. 79 (1982): 5006-5010.

100. Palmer JD, Jansen RK, Michaels HJ, Chase MW and Manhart JW. "Chloroplast DNA variation and plant phylogeny." Annals of Missouri Botanical Garden.75 (1988): 1180-1206.

101. Paran I, Aftergoot E and Shifriss C. "Variation in Capsicum annum revealed by RAPD and AFLP markers." Euphytica. 99 (1998): 167-173.

102. Pérez de la Torre MC and Escandón AS. "Construction of a molecular identification profile of new varieties of Nierembergia linariaefolia by anchored microsatellites." Electronic Journal of Biotechnology. 3 (2006): 15.

103. Perry KL and Palukaitis P. "Transcription of tomato ribosomal DNA and the organization of the intergenic spacer." Molecular and General Genetics. 221 (1990): 102-112.

104. Prevost A and Wilkinson MJ. "A new system of comparing PCR primers applied to ISSR fingerprinting of potato cultivars." Theoretical and Applied Genetics. 98(1999): 107-112.

105. Prince JP, Loaiza-Figueroa F and Tanksley SD. "Restriction fragment length polymorphism and genetic distance among Mexican accessions of Capsicum." Genome. 35 (1992): 726-732.

106. Przetakiewicz J, Nadolska-Orczyk A and Orczyk W "The use of RAPD and semi-random markers to verify somatic hybrids between diploid lines of Solanum tuberosum L. Cellular and Molecular Biology Letters. 7 (2002): 671-676.

107. Raguso RA, Henzel C, Buchmann SL and Nabhan GP. "Trumpet flowers of the Sonoran Desert: Floral biology of Peniocereus cacti and sacred Datura." International Journal of Plant Sciences. 164 (2003): 877-892.

108. Rakoczy-Trojanowska, M. and H. Bolibok. "Characteristics and a comparison of three classes of microsatellite-based markers and their application in plants." Cellular and Molecular Biology Letters. 9 (2004): 221-38.

109. Ranamukhaarachchi DG, Kane ME, Guy CL and Li QB "Modified AFLP technique for rapid genetic characterization in plants." BioTechniques. 29 (2000): 858-866.

110. Ren N and Timko MP. "AFLP analysis of genetic polymorphism and evolutionary relationships among cultivated and wild Nicotiana species." Genome. 44 (2001): 559-571.

111. Richardson T, Cato S, Ramser J, Kahl G and Weising K. "Hybridization of microsatellites to RAPD: A new source of polymorphic markers." Nucleic Acids Research. 23 (1995): 37983799 .

112. Ridout CJ and Donini P. "Use of AFLP in cereals research." Trends in Plant Science. 4(1999): 76-79.

113. Rio AH and Bamberg JB. "Ten years of research at the US Potato Genebank using molecular markers to study efficiency in the acquisition and management of potato genetic diversity." 88th Annual Meeting of PAA. Scottsbluff, NE. Aug. (2004):8-12.

114. Rio AH and Bamberg JB. "RAPD markers efficiently distinguish heterogenous populations of wild potato (Solanum)." Genetic Resources and Crop Evolution. 47(2000): 115-121.
115. Ritland K and Clegg MT. "Evolutionary analysis of plant DNA sequences. American Naturalist. 130 (1987): S74-S100.

116. Rodriguez JM, Berke T, Engle L and Nienhuis J. "Variation among and within Capsicum species revealed by RAPD markers.' Theoretical and Applied Genetics. 99(1999): 147-156.

117. Ryzhova NN, Goryunova SV, Tomilov AA and Kochieva EZ. "Two types of rDNA internal transcribed spacers (ITSs) in the Capsicum genome.” Doklady Biological Sciences. 387(2002): 539-541.

118. Sakata Y and Lester RN. "Chloroplast DNA diversity in eggplant (Solanum melongena) and related species." Euphytica. 97(1997): 295-301.

119. Santiago-Valentini, E and Olmstead RG. "Phylogenetics of the Antillean Goetzeoideae (Solanaceae) and their relationship within the Solanaceae based on chloroplast and ITS DNA sequence data." Systematic Botany. 23 (2003): 452-460.

120. Saritnum, O and Sruamsiri P. "Random amplified polymorphic DNA analysis of galanga (Alpinia spp.) accessions." CMU Journal. 2 (2003): 159-164.

121. Savolainen V, Spichiger R and Manen JF. "Polyphyletism of Celastrales deduced from a chloroplast non-coding DNA region." Molecular Phylogenetics and Evolution. 7(1997): 145-157.

122. Sazima M, Buzato S and Sazima I. "Dyssochroma viridiflorum (Solanaceae): A reproductively bat-dependent epiphyte from the Atlantic rainforest in Brazil." Annals of Botany. 92 (2003): 725730

123. Scotland RW, Olmstead RG and Bennett JR. "Phylogeny Reconstruction: The Role of Morphology." Systematic Biology. 52(2003): 539-548.

124. Shalk M, Nedelkina S, Schoch G, Batard Y and Werck-Reichhart D. "Role of unusual aminoacid residues in the proximal and distal heme regions of a plant P450, CYP73A1." Biochemistry. 38 (1999): 6093-6103

125. Singh AK, Singh M, Singh AK, Singh R, Kumar S and Kalloo G. "Genetic diversity within the genus Solanum (Solanaceae) as revealed by RAPD markers.” Current Science. 90 (2006): 711-716.

126. Sivolap YM and Kalendar RN. "Genetic polymorphism in barley detected by PCR with arbitrary primers." Russian Journal of Genetics. 31(1995): 1155-1161

127. Smelcerovic A, Verma V, Spitller M, Ahmad SM, Puri SC and Qazi GN. "Phytochemical analysis and genetic characterization of six Hypericum species from Serbia." Phytochemistry. 67(2006): $171-177$

128. Spooner DM, Rios D, Rodriguez F and Ghislain M "Nuclear and chloroplast DNA reassessment of the origin of the first European introductions of cultivated potatoes from the Canary Islands." Botanical Society of America Abstracts. (2006): 749.

129. Spooner, D. M., G. J. Anderson and R. K. Jansen. 1993. Chloroplast DNA evidence for the interrelationships of tomatoes, potatoes and pepinos (Solanaceae). American Journal of Botany. 80: 676-688.

130. Spooner DM, Tivang J, Nienhuis J, Miller JT, Douches DS and Contreras A. "Comparison of four molecular markers in measuring relationships among the wild potato relatives Solanum section Etuberosum (subgenus Potatoe)." Theoretical and Applied Genetics. 92(1996): 532-540.

131. Spooner DM, Van Den Berg RG and Miller JT. "Species and series boundaries of Solanum series Longipedicellata (Solanaceae) and phenetically similar species in ser. Demissa and ser. Tuberosa: Implications for a practical taxonomy of section Petota." American Journal of Botany. 88 (2000): 113-130.

132. Spooner DM, Van Den Berg RG and Bamberg J. "Examination of species boundaries of Solanum series Demissa and potentially related species in series Acaulia and series Tuberosa (sect. Petota)." Systematic Botany. 20 (1995): 295-314 
133. Stebbins GL. "Flowering plants: Evolution Above the Species Level." Belknap, Cambridge, MA (1974).

134. Stedje B and Bukenya-Ziraba R. "RAPD variation in Solanum anguivi Lam. and S. aethiopicum L. (Solanaceae) in Uganda." Euphytica. 131(2003): 293-297.

135. Suganda AG., Sukrasno, N. Yasutaka, Y. Takashi and S. Nobuo. 2006. Random amplified polymorphic DNA analysis to distinguish Brugmansia suaveolens, B. candida and B. versicolor:" Plant Biotechnology. 23 (2000): 519-520.

136. Sylvain S, Patricia FR, Emilce P and Daniel P. "Molecular markers for genetic resource analysis and plant breeding. Cabiers Agricultures. 9 (2000): 311-327.

137. Systma KJ and Hahn WJ. "Molecular systematics: 1997-1999." Progress in Botany. 62(2000): 307-339.

138. Takhtajan A. "Diversity and Classification of Flowering Plants." Columbia University Press, New York. 1997

139. Thomas CM, Vos P, Zabeau M, Jones DA, Norcott KA, Chadwick BP and Jones JD. "Identification of amplified restriction fragment polymorphism (AFLP) markers tightly linked to the tomato Cf-9 gene for resistance to Cladosporium." Plant Journal. 8 (1995): 785-794.

140. Tsumura Y, Ohba K and Strauss SH. "Diversity and inheritance of inter-simple sequence repeat polymorphisms in douglas-fir (Pseudotsuga menziesii) and sugi (Cryptomeria japonica).' Theoretical and Applied Genetics. 92 (1996): 40-45.

141. Verma V, Ahmad SM, Ganaie MM, Basir SF, Rishi Z and Qazi G N. "Ribosomal genes in plants: Phylogenetic importance." [In: Trivedi PC (ed). Advances in Biotechnology. Agrobios India, New Delhi.] (2005): 241-254.

142. Volkov RA, Komarova NY, Panchuk I I and Hemleben V. "Molecular evolution of rDNA external transcribed spacers and phylogeny of sect. Petota (genus Solanum)." Molecular Phylogenetics and Evolution. 29(2003): 187-202.
143. Vos PR, Hogers M, Sleeker M, Reijans T, Lee M, Homes A, Freiters J, Pot J, Peleman M, Kuiper M and Zabeau M. "AFLP: A new concept for DNA fingerprinting." Nucleic Acids Research. 23(1995): 4407-4414.

144. Walsh BM and Hoot SB. "Phylogenetic relationships of Capsicum (Solanaceae) using DNA sequences from two non-coding regions: The chloroplast atpB-rbcL spacer region and nuclear waxy introns." International Journal of Plant Sciences. 162 (2001): 1409-1418.

145. Weising, K., R. G. Atkinson and R. C. Gardner. 1995. Genomic fingerprinting by microsatellite-primed PCR: A critical evaluation. PCR Methods and Applications. 4: 249-255.

146. Welsh J and McClelland M. "Genomic fingerprints produced by PCR with consensus tRNA gene primers.” Nucleic Acids Research. 19 (1991): 861-866.

147. Xu, Y. S., M. S. Clark and E. Pehu. 1993. Use of RAPD markers to screen somatic hybrids between Solanum tuberosum and $S$. brevidens. Plant Cell Reports. 12: 107-109.

148. Zhang J, Wang Z, Li M and Wang B. "Molecular markers and their application in plant population research." Ying Yong Sheng Tai Xue Bao. 11 (2000): 631-636.

149. Zhao ZL, Zhou KY, Dong $\mathrm{H}$ and Xu LS. "Characters of nrDNA ITS region sequences of fruits of Alpinia galanga and their adulterants." Planta Medica. 67 (2001): 381-383.

150. Zietkiewicz E, Rafalski A and Labuda D. "Genome fingerprinting by simple sequence repeat (SSR) -anchored polymerase chain reaction amplification." Genomics. 20 (1994): 176-183.

\section{Cite this article as:}

Masood Majaz Ganaie, Vaseem Raja, Zaffar Ahmad Reshi \&.Vijeshwer Verma. Family Solanaceae: Taxonomy and Modern Trends. Annals of Plant Sciences 7.8 (2018) pp. 2403 2414.

do http://dx.doi.org/10.21746/aps.2018.7.9.1

Source of support: Nil; Conflict of interest: Nil. 